\title{
Erratum to: Alumina microtubes prepared via template-directed pulsed chemical vapor deposition (pulsed CVD)
}

\author{
Amit K. Roy • Stefan Knohl • Werner A. Goedel
}

Published online: 2 November 2011

(C) Springer Science+Business Media, LLC 2011

\section{Erratum to: J Mater Sci}

\section{DOI 10.1007/s10853-011-5391-1}

Page 4817, Fig. 5 unfortunately comprises data on the residual weight of uncoated fibres that were assigned to incorrect values of the abscissa. The correct diagram is given below.

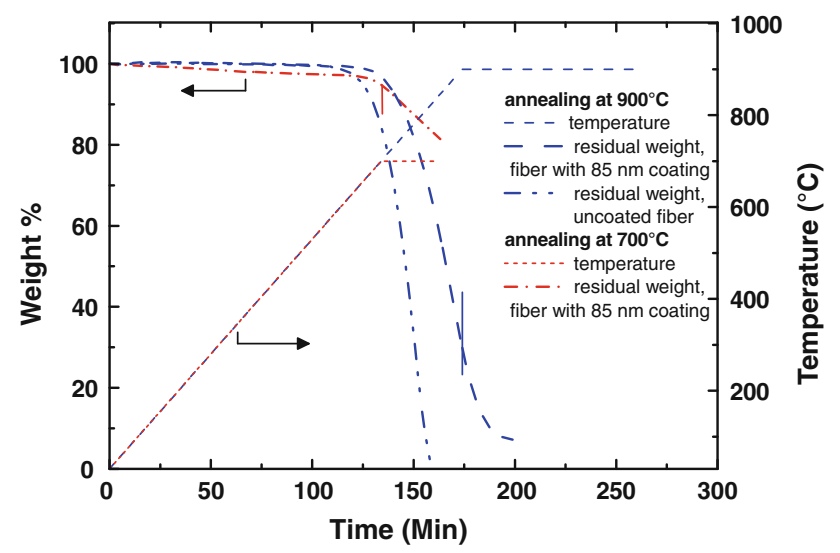

Fig. 5 Thermogravimetric analysis of uncoated and coated fibers in synthetic air. The specimens were heated to the desired temperature (700 or $900{ }^{\circ} \mathrm{C}$, indicated by thin vertical lines) with a constant heating rate of $5^{\circ} \mathrm{C} / \mathrm{min}$ and subsequently held at that temperature
The text passage on page 4818, column 1, paragraph 1, "The uncoated fibers start to lose weight at approximately $300{ }^{\circ} \mathrm{C}$, whereas the coated fibers start to lose weight at approximately $700{ }^{\circ} \mathrm{C}$." should read instead: "The uncoated fibers start to lose weight at approximately $630{ }^{\circ} \mathrm{C}$, whereas the coated fibers start to lose weight at approximately $660{ }^{\circ} \mathrm{C} . "$

The online version of the original article can be found under doi: 10.1007/s10853-011-5391-1.

\footnotetext{
A. K. Roy · S. Knohl · W. A. Goedel ( $\square)$

Physical Chemistry, Institute of Chemistry, Chemnitz University

of Technology, Strasse der Nationen 62, 09111 Chemnitz,

Germany

e-mail: werner.goedel@chemie.tu-chemnitz.de
} 